\title{
Assessment of Radioactivity Contents and Associated Risks in Some Soil Used for Agriculture and Building Materials in Cameroon
}

\author{
Pascal Tchokossa ${ }^{1 *}$, Thomas B. Makon ${ }^{2}$, Robert Martin Nemba ${ }^{2}$ \\ ${ }^{1}$ Department of Physics, Obafemi Awolowo University, Ile-Ife, Nigeria; ${ }^{2}$ Laboratory of Theoretical and Physical Chemistry, De- \\ partment of Inorganic Chemistry, Faculty of Sciences, University of Yaounde I, Yaounde, Cameroon. \\ Email: ${ }^{*}$ ptchokos@yahoo.com
}

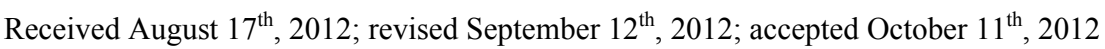

\begin{abstract}
A survey of radioactivity content and associated radiological risks was carried out in various soils used for agriculture and building materials in Cameroon by means of a well-calibrated high-purity germanium detector. Soil samples were collected directly from the agricultural farms and the brick's factories, air-dried at room temperature to a constant mass, crushed, sieved and sealed for at least one month before analysis. The specific activity of ${ }^{238} \mathrm{U}$ ranged from $5.36 \pm 0.39$ to $51.28 \pm 9.67 \mathrm{~Bq} \cdot \mathrm{kg}^{-1}$ with an average of $34.52 \pm 7.18 \mathrm{~Bq} \cdot \mathrm{kg}^{-1} ;{ }^{232} \mathrm{Th}$ from $4.03 \pm 1.03$ to $24.74 \pm 3.10 \mathrm{~Bq} \cdot \mathrm{kg}^{-1}$ with an average of $16.67 \pm 4.28 \mathrm{~Bq} \cdot \mathrm{kg}^{-1} ;{ }^{40} \mathrm{~K}$ ranged from $16.18 \pm 3.11$ to $467.40 \pm 50.80 \mathrm{~Bq} \cdot \mathrm{kg}^{-1}$ with an average of $186.96 \pm$ $16.21 \mathrm{~Bq} \cdot \mathrm{kg}^{-1}$; while that of the fallout ${ }^{137} \mathrm{Cs}$ ranged from 0.00 to $4.79 \pm 1.75 \mathrm{~Bq} \cdot \mathrm{kg}^{-1}$ with an average of $2.32 \pm 0.99$ $\mathrm{Bq} \mathrm{kg}^{-1}$; The mean result obtained for the Representative levels index $\left(\mathrm{I}_{\gamma}\right)$, the radium equivalent $\left(\mathrm{Ra}_{\mathrm{eq}}\right)$, the total absorbed dose rate (ADR), the external hazard index $\left(\mathrm{H}_{\mathrm{ex}}\right)$, the internal hazard index $\left(\mathrm{H}_{\mathrm{in}}\right)$ and the Ceasium intervention levels were $0.52,72.75 \mathrm{~Bq} \cdot \mathrm{kg}^{-1}, 33.73 \mathrm{nGy} \cdot \mathrm{h}^{-1}, 0.20 \mathrm{~Bq} \cdot \mathrm{kg}^{-1}, 0.29 \mathrm{~Bq} \cdot \mathrm{kg}^{-1}$ and $0.0028 \mathrm{~Bq} \cdot \mathrm{cm}^{2}$ respectively. The discrepan- cies of our data can be attributed to several factors such as past nuclear disasters, geological formation, transport process, etc. Although our results are just some fractions of the international standard limit, but still within the same ranges when compared with those obtained elsewhere. This results also will serve as a baseline data for future inves- tigations.
\end{abstract}

Keywords: Radionuclides; Radiological Hazards; Soil; Gamma Spectroscopy; Cameroon

\section{Introduction}

Radionulides that accumulate in soils constitute a direct route of exposure to human population when the contaminated soils are used. Thus, external exposure of human to ionizing radiation from the use of soil has been noted with great concern [1-7]. Soil is of great important in human life. It constitutes the ground from which man settlement is build and through which foods are produced.

Soils and rocks contain natural radionuclides of a wide range of activity levels. This radioactivity can be transported to the surface by several processes: tectonic movement, volcanic activity, ore/coal mining and groundwater flow. The transportation by groundwater flow and similar mechanism depends on the solubility and chemical reactions of the radioactive substance, and the porosity of the ground. Migration plays an important role in the final storage of radioactive waste.

\footnotetext{
"Corresponding author.
}

The most severe civil nuclear reactor accident at Chernobyl power station occurred on $26^{\text {th }}$ April $1986[8,9]$. The post-impact assessment program for the estimation of migration dose as a component of radiation burden of the populace in Cameroon was put in place because of the worldwide distribution of its radioactive effluents.

Cameroon is surrounded by countries having nuclear reactors and it is not far from the Sahara where some atmospheric weapons tests took place (Figure 1). With particular reference of the lessons and experiences of the Chernobyl-4 accident, there is a growing need to assure the Cameroon public over the concern about the possibility of nuclear accident with transboundary consequences which may nevertheless occur in spite of any adequate nuclear safety criteria by countries operating nuclear (research or power) reactors, particularly in Africa.

During the years after those nuclear accidents, the bioactivity and environmental mobility of radiocesium declines markedly, resulting in large changes in contamination of soils, surface water, foodstuffs, etc. The sorption 


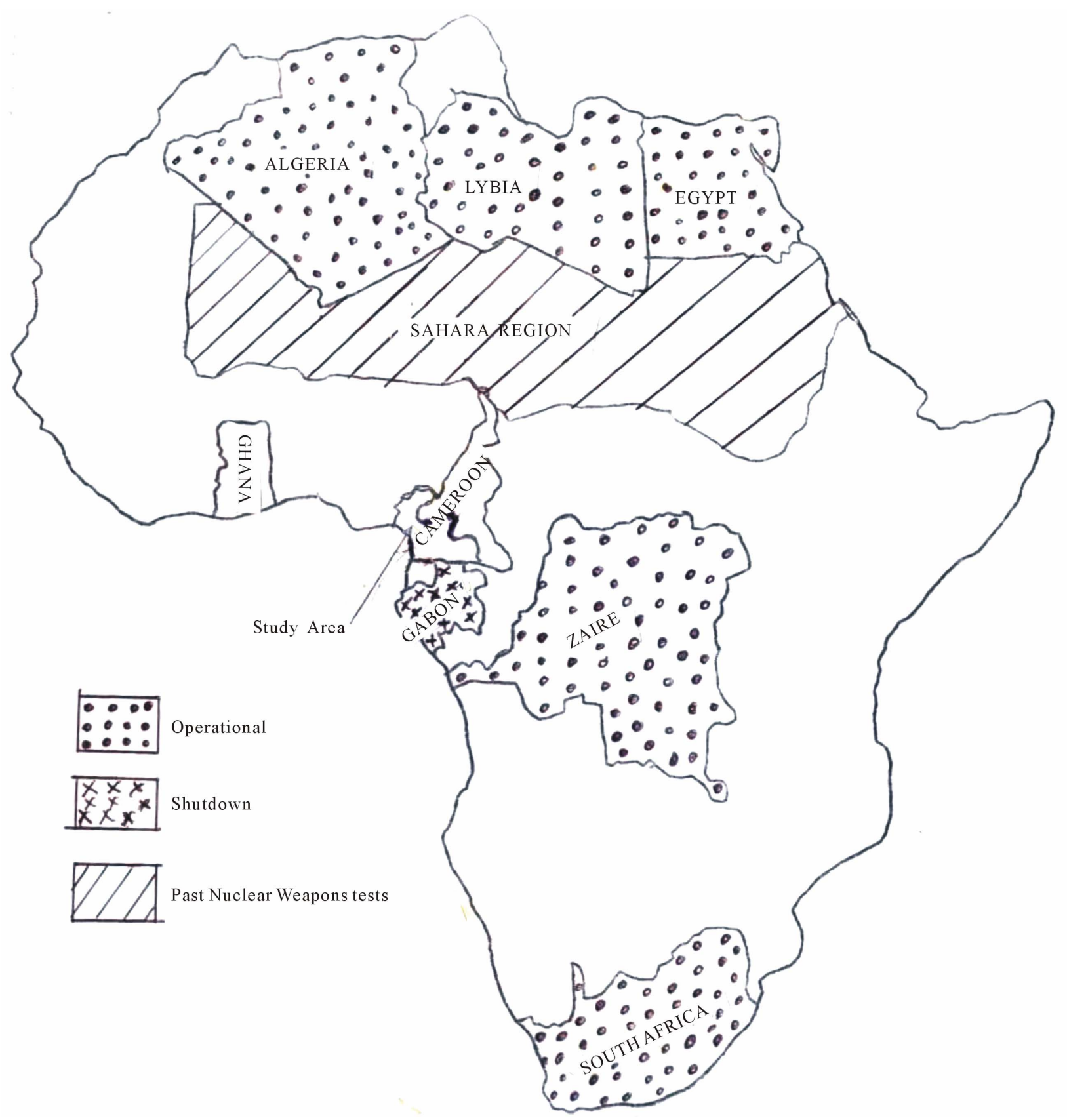

Figure 1. Map of Africa showing countries having nuclear reactors.

of radiocesium to soils and sediments has shown that Cs is selectively bound to specific sorption sites on illitic clay minerals where it is available for ion-exchange with ions, which have a similar hydrated radius, specifically potassium and ammonium [10]. Over time, however radiocesium slowly diffuses into the illite lattice know as "fixation". Radiocesium fixation in soils and sediments are crucial due to its long-term mobility and bioavailability.

In recent times, there is an increased awareness of the effects of environmental radiation from natural radioactivity which has been enhanced by some environmental fields such as rocks, soils, water air, etc. Attention has been given to radioactivity contents and radiation levels in various types of solid due to naturally occurring radioactivity.

Radiation, by its very nature is harmful to life. Depending on the doses, it can induce cancer, genetic and organs damages, cell killing and also rapid death.

Many research works have been carried out on radio- 
activity measurement throughout the world [1,3,7,11]. Here in Nigeria, Tchokossa and his co-workers reported the results of many investigations on the distribution of radioactivity content in various environmental matrices [12-19], while in Cameroon, Makon et al. carried out similar research in some edible vegetable cultivated and consumed worldwide [20]. Cameroon is located at the center of both operational and non-operational nuclear reactors and industries (Figure 1), and to the best of my knowledge, there is no published or on-going works on the survey of Cameroonian's soil.

This present work aimed to provide information on the radiation levels in the soil and the resulting contribution of past nuclear operation carried out that may have being accumulated in soil. The data generated will not only help to design a radiation mapping for agricultural lands and building materials, but also will be use as baseline data for future investigations, government, policy makers and the general public.

\section{Materials and Methods}

A total of 45 soil samples were collected from nine towns across five provinces of the country. At each location, well described elsewhere [20], the samples were collected at the depth between $0-30 \mathrm{~cm}$, at the four corners and the center of a square frame of $1 \mathrm{~m}$ size and later composed to make a single sample. Samples were collected in their natural form, dried at room temperature to a constant weight, grounded and sieved to a $2 \mathrm{~mm}$ size. Each sample was sealed in cylindrical plastic containers. The standard reference sample and the background which was an empty container have the same geometry like the sample containers. The sealed samples were kept for at least 28 days to allow a stage of secular equilibrium to reach before gamma spectrometry analysis commenced.

The counting equipment well described elsewhere [12, 16] was a Canberra vertical high-purity coaxial germanium (HPGe) crystal detector, model GC 2018 - 7500, serial number b87063 enclosed in a $100 \mathrm{~mm}$ thick lead shield and coupled to a Canberra Multichannel Analysing (MCA) computer system. The energy and efficiency calibrations were done using a well calibrated standard soils sources supplied by the International Atomic Energy Agency (IAEA), Vienna, Austria (Reference Material IAEA-375 for radionuclides and trace elements in soil) and some radioactive point sources from the Isotopes Products Laboratories, Burbank, California, USA. The advantage of gamma ray spectrometry is its ability to measure gamma emitters directly in the original sample without the need for chemical separation. It allows both qualitative identification and quantitative determination of the radionuclides in the sample. The counting time for both the sample and the background was $36,000 \mathrm{~s}$. The photopeaks observed with regularity were identified to belong not only to the naturally occurring series decay radionuclide headed by ${ }^{238} \mathrm{U}$ and ${ }^{232} \mathrm{Th}$, and non-series natural radionuclide ${ }^{40} \mathrm{~K}$, but also the presence of ${ }^{137} \mathrm{Cs}$ in most of the soils samples investigated. Other radionuclides if present, appeared rather infrequently at low levels or occurred at levels below the maximum detectable limits (MDL) statistically determined a two-standard deviation analytical error. The characteristics of the selected gamma-emitting radionuclides used as monitor lines for this work are as shown in Table 1. The ${ }^{226} \mathrm{Ra}$ $\left({ }^{238} \mathrm{U}\right)$ activity was estimated from ${ }^{214} \mathrm{~Pb}$ at $351.9 \mathrm{keV}$, ${ }^{214} \mathrm{Bi}$ at 609.3 and $1120.3 \mathrm{keV}$; that of ${ }^{232} \mathrm{Th}$ was from ${ }^{208} \mathrm{Tl}$ at $583.2 \mathrm{keV}$ and ${ }^{228} \mathrm{Ac}$ at $911.1 \mathrm{keV} .{ }^{40} \mathrm{~K}$ and ${ }^{137} \mathrm{Cs}$ were determined directly from the 1460.3 and $661.6 \mathrm{keV}$ gamma-emission respectively. The activities of the radionuclides in the measured samples were computed from the difference between the net peak and net background areas, accumulation time, absolute peak efficiency, absolute $\gamma$-ray emission probability and the sample mass. Duplicate analyses were conducted on all soil samples to check for the reproductivity of the results and the stability of the counting system. The total uncertainty in the measured concentrations was estimated from the combined uncertainties in the homogeneity of the samples, their position with respect to the detector, the calibration procedure, the peak area determination and the background correction.

\section{Results and Discussion}

\subsection{Activity Concentration}

The average concentrations of the radionuclides observed with regularity in the soil samples analyzed by gammaspectrometry are given in Table 2 .

Except for ${ }^{40} \mathrm{~K}$ and ${ }^{137} \mathrm{Cs}$, all the gamma-lines detected came from the ${ }^{238} \mathrm{U}$ and ${ }^{232} \mathrm{Th}$ decay series. The total specific activity from each radionuclide determined at two-standard deviation analytical error was calculated on the basis of a mean value obtained from each sampling location taken from a particular depth. The ${ }^{238} \mathrm{U}$ concentrations ranged from $5.36 \pm 0.39$ to $51.28 \pm 9.67 \mathrm{~Bq} \cdot \mathrm{kg}^{-1}$ with an average of $34.52 \pm 7.18 \mathrm{~Bq} \cdot \mathrm{kg}^{-1}$. ${ }^{232} \mathrm{Th}$ from $4.03 \pm 1.03$ to $24.74 \pm 3.10 \mathrm{~Bq} \cdot \mathrm{kg}^{-1}$ with an average of $16.67 \pm 4.28 \mathrm{~Bq} \cdot \mathrm{kg}^{-1} \cdot{ }^{40} \mathrm{~K}$ from $16.18 \pm 3.11$ to $467.40 \pm$ $50.80 \mathrm{~Bq} \cdot \mathrm{kg}^{-1}$ with an average of $186.96 \pm 16.21 \mathrm{~Bq} \cdot \mathrm{kg}^{-1}$ and lastly ${ }^{137} \mathrm{Cs}$ from 0.00 to $4.79 \pm 1.75 \mathrm{~Bq} \cdot \mathrm{kg}^{-1}$ with an average $2.32 \pm 0.99 \mathrm{~Bq} \cdot \mathrm{kg}^{-1}$.

For ${ }^{40} \mathrm{~K}$, the highest activity concentration was detected in location 5 (Bamenda), in fact geographically, the town is made up of series of mountains and valleys where most of the agricultural lands lie. The lowest was 
Table 1. Characteristics of selected gamma-emitting radio-nuclides [42].

\begin{tabular}{|c|c|c|c|c|}
\hline Radionuclides & Source & Half life $T_{1 / 2}(y r)$ & Gamma energy $E_{\gamma}(\mathrm{keV})$ & Gamma intensity $I_{\gamma}(\%)$ \\
\hline${ }^{214} \mathrm{~Pb}$ & ${ }^{238} \mathrm{U}$ decay & $1.6 \times 10^{3}$ & 351.9 & 38.9 \\
\hline${ }^{214} \mathrm{Bi}$ & ${ }^{238} \mathrm{U}$ decay & $1.6 \times 10^{3}$ & 609.3 & 43.3 \\
\hline${ }^{214} \mathrm{Bi}$ & ${ }^{238} \mathrm{U}$ decay & $1.6 \times 10^{3}$ & 1120.3 & 15.7 \\
\hline${ }^{238} \mathrm{Ac}$ & ${ }^{232} \mathrm{Th}$ decay & $1.41 \times 10^{10}$ & 911.1 & 27.7 \\
\hline${ }^{208} \mathrm{Tl}$ & ${ }^{232} \mathrm{Th}$ decay & $1.41 \times 10^{10}$ & 583.2 & 85.8 \\
\hline${ }^{40} \mathrm{~K}$ & Primordial & $1.28 \times 10^{9}$ & 1460.8 & 10.7 \\
\hline${ }^{137} \mathrm{Cs}$ & Chernobyl and nuclear weapons tests & 30 & 661.6 & 85.2 \\
\hline
\end{tabular}

Table 2. Activity concentration (Bq/kg).

\begin{tabular}{|c|c|c|c|c|c|c|c|c|}
\hline Locations & ${ }^{40} \mathrm{~K}$ & & ${ }^{238} \mathbf{U}$ & & ${ }^{232} \mathrm{Th}$ & & ${ }^{137} \mathrm{Cs}$ & \\
\hline & Range & Mean & Range & Mean & Range & Mean & Range & Mean \\
\hline 1 & $177.58-265.02$ & $221.30 \pm 16.60$ & $32.79-42.82$ & $37.61 \pm 6.03$ & $17.76-23.40$ & $21.45 \pm 5.63$ & $3.96-4.31$ & $4.14 \pm 1.38$ \\
\hline 2 & $66.19-292.65$ & $156.06 \pm 12.14$ & $27.57-51.28$ & $39.34 \pm 9.38$ & $10.62-20.04$ & $16.11 \pm 4.21$ & $2.55-3.38$ & $2.98 \pm 1.38$ \\
\hline 3 & $32.58-122.07$ & $76.48 \pm 14.32$ & $24.67-36.49$ & $27.28 \pm 6.69$ & $10.47-18.34$ & $15.18 \pm 4.56$ & ND & ND \\
\hline 4 & $45.38-224.23$ & $145.60 \pm 10.92$ & $5.36-42.85$ & $26.73 \pm 5.26$ & $6.08-24.74$ & $16.16 \pm 2.30$ & $1.32-4.79$ & $3.06 \pm 1.19$ \\
\hline 5 & $453.20-467.40$ & $465.30 \pm 43.70$ & $46.92-49.71$ & $49.22 \pm 12.11$ & $20.44-23.93$ & $22.19 \pm 7.37$ & ND - 2.87 & $2.66 \pm 1.09$ \\
\hline 6 & $187.66-209.73$ & $191.97 \pm 14.78$ & $32.40-49.38$ & $40.89 \pm 7.70$ & $17.72-21.44$ & $19.58 \pm 6.06$ & ND - 2.24 & $2.08 \pm 0.76$ \\
\hline 7 & $162.87-213.16$ & $182.09 \pm 13.83$ & $39.86-49.86$ & $47.13 \pm 6.70$ & $12.04-16.23$ & $14.75 \pm 3.25$ & ND - 2.04 & $1.90 \pm 0.68$ \\
\hline 8 & $211.71-232.69$ & $224.63 \pm 17.47$ & $27.30-38.24$ & $34.46 \pm 10.10$ & $17.50-21.33$ & $19.55 \pm 3.86$ & ND - 2.32 & $2.28 \pm 0.83$ \\
\hline 9 & $16.18-32.42$ & $19.23 \pm 2.14$ & $6.80-10.22$ & $8.00 \pm 0.67$ & $4.03-8.22$ & $5.09 \pm 1.27$ & ND - 1.98 & $1.76 \pm 0.61$ \\
\hline Mean & $16.18-467.40$ & $186.96 \pm 16.21$ & $5.36-51.28$ & $34.52 \pm 7.18$ & $4.03-24.74$ & $16.67 \pm 4.28$ & ND - 4.79 & $2.32 \pm 0.99$ \\
\hline
\end{tabular}

detected in location 9 (Limbe), probably because the sampling point is located to the upper slope part of the city, and the soil there are prone to a high level of erosion which may result in leaching of the soil. This pattern has been confirmed as we moved down the slope. This is favourable as a result of erosion which washes out soil to settle at the valley. ${ }^{40} \mathrm{~K}$ is a naturally occurring radionuclide present abundantly in the earth crust as one of its major constituents. ${ }^{40} \mathrm{~K}$ content in soil shows a more homogeneous distribution in the horizontal micro scale. The variability of ${ }^{40} \mathrm{~K}$ among locations could be due to the differences in land management, for example, fertilization, plowing practices, geology and geography.

For ${ }^{238} \mathrm{U}$, the highest activity concentration was found in location 2 (Ezeka) while the least was obtained in location 4 (Edea). In nature, uranium consists of primary two isotopes ${ }^{238} \mathrm{U}$ and ${ }^{235} \mathrm{U}$, of which the former is the most abundant $99.73 \%$ [21].

While for ${ }^{232} \mathrm{Th}$, the highest activity concentration was obtained in Edea (location 4) and the least in Limbe (location 9). ${ }^{238} \mathrm{U}$ and ${ }^{232} \mathrm{Th}$ were detectable in all the soils sample with the former almost double that of ${ }^{232} \mathrm{Th}$ except in some few cases.

Geologically, the bedrocks consist of coarse to medium sand, subordinate slit, gneiss and granites which have affinity to ${ }^{238} \mathrm{U}$ and ${ }^{232} \mathrm{Th}$. Slight variation in the radioactivity content in soil may be observed with different locations mainly due to the type of soil, soil formation and soil transport process.

For ${ }^{137} \mathrm{Cs}$, the highest activity concentration was found in location 4 (Edea) while it was not detectable in location 3 (Douala). This higher presence of ${ }^{137} \mathrm{Cs}$ in locations 7, 1 and especially 4 may be attributed to the natural reactor in Oklo. In fact, during 1972 a natural nuclear reactor has been detected at Oklo in Gabon (South of Cameroun) [22]. It was critical about $1.8 \times 10^{9}$ years ago, and has generated totally 15,000 MW-years during his life-time of 600,000 years. The exact analysis of the composition of the fission products revealed that it was a light-water-moderated and- cooled reactor of the BWR (Boiling Water) type. The steam penetrated the overlaying rocks, dissolved further uranium ore, which was car- 
ried into the core by the condensate flow (automatic recharging during operation). The results of this natural long-term waste storage experiment can be compared to shorter man-made experiments of the order of 10 years duration [23]. It was pointed out that this waste was not encapsulated and that the main part of the plutonium is still in the reaction zone. Also Bamenda and Buea at locations 5 and 8 respectively were not too far from another natural disaster namely Lake Nyos.

Lake Nyos which is a crater-lake was formed a few hundred years ago in the highlands of Northwestern Cameroun during one of the volcanic eruptive activity. The Lake, located about $6^{\circ} 26^{\prime} \mathrm{N}$ latitude and $10^{\circ} 16^{\prime} \mathrm{E}$ longitude is $208 \mathrm{~m}$ deep and contains $1.32 \times 10^{8} \mathrm{~m}^{3}$ of water [24]. Geologically, the area lies within a volcanic active basement region with volcanic ask material overlying the basement. The lake Nyos Dam was formed at the time of the formation of the Crater Lake. This Dam has been eroding at a geologically alarming rate. Granitic bedrock had therefore been exposed along a $40 \mathrm{~m}$ thick dam. This was left at its narrowest point where water overflows and spills from the lake through a surface path down the cliff-face of the dam during the rainy season. A lethal explosion led to the release of gas from Lake Nyos in the night of 21st August 1986, killing 1746 people, several thousand of cattle and other animals by suffocation as the gas cloud swept down the valleys to the North and through the valleys of Cha, Nyos and Subum. The gas explosion generated a huge seiche estimated as high as $75 \mathrm{~m}$ [25] which uprooted trees and bamboo forest on the foreshore to the South of the lake. By September 14, 1986 , the lake surface was still reddish brown in colour and littered with floating trees and debris. The disaster affected all settlements downstream within $25 \mathrm{~km}$ from the Lake. The gas explosion occurred without any previous warming, although two years earlier, on the 15 th August 1984, a similar disastrous emission of carbon dioxide occurred in Lake Monoun, killing 37 peoples [26].

The occurrence of this fallout ${ }^{137} \mathrm{Cs}$ in soil in Cameroon may also be due to the Sahara's atmospheric nuclear weapon tests of the 50's and 60's which were the primary causes of high levels of global fallout. Radioactive materials were diffused depending on the extent and form of the emission, and are formed even in areas otherwise uninfluenced by human activity. It is known that small quantities of fission-products residues $\left({ }^{137} \mathrm{Cs}\right.$ and ${ }^{90} \mathrm{Sr}$ ) from atmospheric weapons test (AWTs) are slowly being purged from the food chain [27].

\subsection{Estimation of the Radiological Hazard Indices}

Table 3 present some radiological effects indices such as the Absorbed dose rate, the Radium Equivalent activity concentration, the Representative Level index, External Hazard Index $\left(\mathrm{H}_{\mathrm{ext}}\right)$, Internal Hazard Index $\left(\mathrm{H}_{\mathrm{in}}\right)$ and the Caesium-137 Intervention Levels.

\subsubsection{Total Air Absorbed Dose Rate (D)}

The total Absorbed Dose Rate D (in $\mathrm{nGy} \cdot \mathrm{hr}^{-1}$ ) at $1.0 \mathrm{~m}$ above the ground was estimated using the empirical formula: [28,29].

$$
\mathrm{D}=0.042 \mathrm{~A}_{\mathrm{K}}+0.428 \mathrm{~A}_{\mathrm{U}}+0.666 \mathrm{~A}_{\mathrm{Th}}
$$

as a partial evaluation of the radiological hazard of ${ }^{40} \mathrm{~K}$, ${ }^{238} \mathrm{U}$ and ${ }^{232} \mathrm{Th}$. Here $\mathrm{A}_{\mathrm{K}}, \mathrm{A}_{\mathrm{U}}$ and $\mathrm{A}_{\mathrm{Th}}$ are the specific activity concentration for ${ }^{40} \mathrm{~K},{ }^{238} \mathrm{U}$ and ${ }^{232} \mathrm{Th}$ respectively. The results are contained in Table 3 . The absorbed dose rate values ranged between $7.62-55.39 \mathrm{nGy} \cdot \mathrm{hr}^{-1}$ with a mean of $33.73 \pm 6.46 \mathrm{nGy} \cdot \mathrm{hr}^{-1}$. The least absorbed dose rate was recorded in location 9 (Limbe), while the highest was obtained in location 5 (Bamenda). Using an outdoor occupancy factor of 0.20 and the conversion factor of $0.70 \mathrm{~Sv} / \mathrm{Gy}$ [29], the effective dose equivalent $\left(\mathrm{H}_{\mathrm{E}}\right)$ arising from this average absorbed dose in air is 35.10 $\mu \mathrm{Sv} / \mathrm{y}$. This value is just about $3.5 \%$ of the $1.0 \mathrm{mSv} / \mathrm{y}$ recommended by the International Commission on Radiological Protection [30,31] as the maximum permissible $\mathrm{H}_{\mathrm{E}}$ for members of the public. Therefore the area may be considered as safe for habitation.

\subsubsection{Radium Equivalent Activity $\left(\mathbf{R a}_{\mathrm{eq}}\right)$}

In comparing the radioactivity of materials that contain $\mathrm{Ra}$, Th and K, a common index termed Radium Equivalent activity $\left(\mathrm{Ra}_{\mathrm{eq}}\right)$ is required to obtain the total activity and is also used to assess the gamma radiation hazards. Since $98 \%$ of the radiological effects of the uraniumseries are produced by radium and its daughter products [32], the contribution from ${ }^{238} \mathrm{U}$ and the other ${ }^{226} \mathrm{Ra}$ precursors is usually ignored, so that the $\mathrm{Ra}_{\mathrm{eq}}$ can be expressed as [33-34]:

$$
\begin{aligned}
\mathrm{Ra}_{\mathrm{eq}}= & 370 \mathrm{~Bq} \cdot \mathrm{kg}^{-1} \\
& \cdot\left(\frac{\mathrm{A}_{\mathrm{Ra}}}{370 \mathrm{~Bq} / \mathrm{kg}}+\frac{\mathrm{A}_{\mathrm{Th}}}{259 \mathrm{~Bq} / \mathrm{kg}}+\frac{\mathrm{A}_{\mathrm{K}}}{4810 \mathrm{~Bq} / \mathrm{kg}}\right)
\end{aligned}
$$

or

$$
\mathrm{Ra}_{\mathrm{eq}}=\mathrm{A}_{\mathrm{Ra}}+1.43 \mathrm{~A}_{\mathrm{Th}}+0.077 \mathrm{~A}_{\mathrm{K}}
$$

where $A_{R a}, A_{T h}$ and $A_{K}$ are the activity concentrations of ${ }^{226} \mathrm{Ra},{ }^{232} \mathrm{Th}$ and ${ }^{40} \mathrm{~K}$ in $\mathrm{Bq} \cdot \mathrm{kg}^{-1}$ respectively. The results of $\mathrm{Ra}_{\mathrm{eq}}$ ranged between $16.76-116.78 \mathrm{~Bq} \cdot \mathrm{kg}^{-1}$ obtained in locations 9 (Limbe) and 5 (Bamenda) respectively, with an average of $72.75 \mathrm{~Bq} \cdot \mathrm{kg}^{-1}$. On the average, $\mathrm{Ra}_{\mathrm{eq}}$ concentration was found to be $85.32 \mathrm{~Bq} / \mathrm{kg}$ for location 1 (Yaounde, the country's capital), $54.88 \mathrm{~Bq} / \mathrm{kg}$ for location 3 (Douala, the most popular city). However, all the values obtained here for radium equivalent activity fall 
Table 3. Derived radiological hazard indices.

\begin{tabular}{|c|c|c|c|c|c|c|}
\hline Locations & $\begin{array}{l}\text { Absorbed } \\
\text { Dose } \\
\text { Rate } \\
\left(\mathbf{n G y} \cdot \mathbf{h r}^{-1}\right)\end{array}$ & $\begin{array}{l}\text { Radium } \\
\text { Equivalent } \\
\text { Activity } \\
\left(\mathbf{B q} \cdot \mathbf{k g}^{-1}\right)\end{array}$ & $\begin{array}{l}\text { Representative } \\
\text { Levels } \\
\text { Index } \\
\mathbf{I}_{\gamma} \\
\end{array}$ & $\begin{array}{l}\text { External } \\
\text { Hazard } \\
\text { Index }\left(\mathrm{H}_{\mathrm{ex}}\right) \\
\left(\mathrm{Bq} \cdot \mathrm{kg}^{-1}\right)\end{array}$ & $\begin{array}{l}\text { Internal } \\
\text { Hazard } \\
\text { Index }\left(\mathrm{H}_{\text {in }}\right) \\
\left(\mathbf{B q} \cdot \mathbf{k g}^{-1}\right)\end{array}$ & $\begin{array}{l}\text { Ceasium } \\
\text { Intervention } \\
\text { Levels } \\
\left(\mathrm{Bq} \cdot \mathrm{cm}^{-2}\right) \\
\end{array}$ \\
\hline 1 & 39.68 & 85.32 & 0.61 & 0.23 & 0.33 & 0.0021 \\
\hline 2 & 34.12 & 74.39 & 0.53 & 0.20 & 0.31 & 0.0016 \\
\hline 3 & 25.00 & 54.88 & 0.38 & 0.15 & 0.22 & \\
\hline 4 & 28.32 & 61.05 & 0.44 & 0.16 & 0.24 & 0.0016 \\
\hline 5 & 55.39 & 116.78 & 0.86 & 0.31 & 0.45 & 0.0012 \\
\hline 6 & 38.60 & 83.67 & 0.60 & 0.23 & 0.34 & 0.0011 \\
\hline 7 & 37.64 & 82.24 & 0.58 & 0.22 & 0.35 & 0.001 \\
\hline 8 & 37.20 & 79.71 & 0.57 & 0.21 & 0.31 & 0.0068 \\
\hline 9 & 7.62 & 16.76 & 0.12 & 0.05 & 0.07 & 0.0071 \\
\hline Mean & 33.73 & 72.75 & 0.52 & 0.20 & 0.29 & 0.0028 \\
\hline
\end{tabular}

far below the criterion limit of $370 \mathrm{~Bq} \cdot \mathrm{kg}^{-1}$ [34]. It is apparent that the $\mathrm{Ra}_{\mathrm{eq}}$ originating from different regions shows some variations, which are likely to be related to the type of soil, transport process, etc. This is important in selecting suitable soils not only for construction but also for agricultural purposes.

\subsubsection{Representative Level Index $\left(I_{\gamma}\right)$}

Another radiation hazard index called The Representative Levels index $\mathrm{I}_{\mathrm{yr}}$ is given by[35]:

$$
I_{\gamma}=\left(\frac{A_{\mathrm{Ra}}}{150 \mathrm{~Bq} / \mathrm{kg}}+\frac{\mathrm{A}_{\mathrm{Th}}}{100 \mathrm{~Bq} / \mathrm{kg}}+\frac{\mathrm{A}_{\mathrm{K}}}{1500 \mathrm{~Bq} / \mathrm{kg}}\right)
$$

where $A_{R a}, A_{T h}$ and $A_{K}$ are the radioactivity concentrations of ${ }^{226} \mathrm{Ra}\left(\right.$ or $\left.{ }^{238} \mathrm{U}\right),{ }^{232} \mathrm{Th}$ and ${ }^{40} \mathrm{~K}$ in $\mathrm{Bq} \cdot \mathrm{kg}^{-1}$ respectively. The Representative Level Index ranged between $0.12-0.86$ with an average of 0.52 . The least and the highest were investigated in locations 9 (Limbe) and 5 (Bamenda). It should be noted that all $\mathrm{I}_{\gamma}$ values observed fall within a very narrow range and are less than unity, the upper limit for the representative level index. These confirm that the soil investigated exhibit very low gamma-radiation level.

\subsubsection{External Hazard Index $\left(\mathrm{H}_{\mathrm{ext}}\right)$}

This index enable us to estimate the radiation dose expected to be delivered externally if a building is constructed using these materials. The external hazard index $\left(\mathrm{H}_{\mathrm{ex}}\right)$ was obtained as follow [36,37]:

$$
\mathrm{H}_{\mathrm{ex}}=\left(\frac{\mathrm{A}_{\mathrm{Ra}}}{370}+\frac{\mathrm{A}_{\mathrm{Th}}}{259}+\frac{\mathrm{A}_{\mathrm{K}}}{4810}\right)
$$

The results shown in table revealed that the external hazard index $\mathrm{H}_{\mathrm{ex}}$ ranged between 0.05 and $0.31 \mathrm{~Bq} \cdot \mathrm{kg}^{-1}$ from locations 9 (Limbe) and 5 (Bamenda) respectively, with a mean of $0.20 \mathrm{~Bq} \cdot \mathrm{kg}^{-1}$. The overall results still below the limit of $1 \mathrm{~Bq} \cdot \mathrm{kg}^{-1}$. Hence it is safe as building materials.

\subsubsection{Internal Hazard Index $\left(\mathrm{H}_{\mathrm{in}}\right)$}

The internal exposure to ${ }^{222} \mathrm{Rn}$ and its progenies is controlled by the internal hazard index $\left(\mathrm{H}_{\mathrm{in}}\right)$ which is given by $[38,39]$ :

$$
\mathrm{H}_{\text {in }}=\left(\frac{\mathrm{A}_{\mathrm{Ra}}}{185}+\frac{\mathrm{A}_{\mathrm{Th}}}{259}+\frac{\mathrm{A}_{\mathrm{K}}}{4810}\right)
$$

$\mathrm{H}_{\text {in }}$ ranged between 0.07 and $0.45 \mathrm{~Bq} \cdot \mathrm{kg}^{-1}$ from locations 9 (Limbe) and 5 (Bamenda) with a mean of 0.29 $\mathrm{Bq} \cdot \mathrm{kg}^{-1}$ as contained in Table 1. Both $\mathrm{H}_{\mathrm{ex}}$ and $\mathrm{H}_{\mathrm{in}}$ recorded the lowest and the highest of their values in the same locations respectively. The highest value of $\mathrm{H}_{\text {in }}$ is still below the limit of $1 \mathrm{~Bq} \cdot \mathrm{kg}^{-1}$ [40] for the safe use of material in the construction of dwellings.

\subsubsection{Caesium Intervention ( $\left.\mathrm{I}_{\mathrm{Cs}-137}\right)$}

Also the Caesium-137 intervention was computed from the following equation [41]:

$$
\mathrm{I}_{\mathrm{Cs}-137}=\left(\frac{\mathrm{A}_{\mathrm{Cs}-137} x \cdot \mathrm{M}}{\mathrm{A}}\right)
$$

where $\mathrm{A}_{\mathrm{Cs}-137}$ is the activity per unit mass of Cs-137

$\mathrm{M}$ : the mass of the sample converted in $\mathrm{kg}$ and

A: the sampling area in $\mathrm{cm}^{2}$.

From the Table 1, $\mathrm{I}_{\mathrm{Cs}-137}$ ranged between 0.0010 and $0.0071 \mathrm{~Bq} \cdot \mathrm{cm}^{-2}$, with a mean of $0.0028 \mathrm{~Bq} \cdot \mathrm{cm}^{-2}$. The lowest and the highest were obtained respectively in lo- 
cations 7 (Lolodorf) and 9 (Limbe), due to the erosion process and underground migration of radionuclides. In fact Limbe is almost located at the sea levels.

\section{Conclusion and Recommendations}

Natural Occurring Radioactive Materials and man-made Cs-137 as well as the derived radiological hazards have being investigated in soil used for agriculture and building materials in some regions in Cameroon, using a well calibrated gamma-spectrometer system. The mean specific activity obtained was $186.96 \pm 16.21,34.52 \pm 7.18$, $16.67 \pm 4.28$ and $2.32 \pm 0.99 \mathrm{~Bq} \cdot \mathrm{kg}^{-1}$ for ${ }^{40} \mathrm{~K},{ }^{238} \mathrm{U},{ }^{232} \mathrm{Th}$ and ${ }^{137} \mathrm{Cs}$ respectively. The mean for the Absorded Dose rate, Radium Equivalent, Representative Level Index, External hazard index, Internal hazard index and Ceasium Intervention Level were $3.73 \mathrm{nGy} \cdot \mathrm{h}^{-1}, 72.75$ $\mathrm{Bq} \cdot \mathrm{kg}^{-1}, 0.52,0.20 \mathrm{~Bq} \cdot \mathrm{kg}^{-1}, 0.29 \mathrm{~Bq} \cdot \mathrm{kg}^{-1}$ and 0.0028 $\mathrm{Bq} \cdot \mathrm{cm}^{-2}$ respectively. These fall within the world ranges for building materials and soil. The relative higher radioactivity content in Bamenda could be attributed to the Athmospheric Nuclear weapon test and the natural disaster that took place in the 60's and 1986 respectively. Calculations of the derived radiological indices for all the investigated soils showed that none exceeds the recommended levels for external radiation exposure. In regard to the above results, the commonly used soil in those areas could be safely used for agriculture and building materials. Meanwhile better characterization of humus, soil mineralogy and regular radiological monitoring are necessary since accumulated doses may result in deleterious effects.

\section{REFERENCES}

[1] A. G. E. Abbady, "Estimation of Radiation Hazard Indices from Sedimentary Rocks in Upper Egypt," Applied Radiation and Isotopes, Vol. 60, No. 1, 2004, pp. 111-114. doi:10.1016/j.apradiso.2003.09.012

[2] T. B. Kirchner, J. L. Webb, R. Arimoto, D. A. Schoep and B. D. Steward, "Variability in Background Levels of Surface Soil Radionuclides in the Vicinity of the US DOE Waste Isolation Pilot Plant," Journal of Environmental Radioactivity, Vol. 60, No. 3, 2002, pp. 275-291. doi:10.1016/S0265-931X(01)00088-1

[3] I. S. Bikit, et al., "The Radioactivity of Vojvodina Agricultural Soil," Archive of Oncology, Vol. 9, No. 4, 2001, pp. 261-262.

[4] A. S. Mollah, G. U. Ahmed, S. R. Husain and M. M. Rahman, "The Natural Radioactivity of Some Building Materials Used in Bangladesh," Health Physics, Vol. 50, No. 6, 1986, pp. 849-851.

[5] I. P. Farai and J. A. Ademola, "Population Dose Due to Building Materials in Ibadan, Nigeria," Radiation Protection and Dosimery, Vol. 95, No. 1, 2001, pp. 69-73. doi:10.1093/oxfordjournals.rpd.a006527
[6] J. B. Olomo, P. Tchokossa and C. A. Aborisade, "Study of Radiation Protection Guidelines in the Use of Building Materials for Urban Dwellings in South-West Nigeria," Nigerian Journal of Physics, Vol. 50, No. 6, 2003, pp. 835-838.

[7] A. S. Mollah, M. M. Rahman and S. R. Husain, "Distribution of $\gamma$-Emitting Radionuclides in Soils at the Atomic Energy Research Establichment, Savar, Bangladesh," Health Physics, Vol. 50, No. 6, 1986, pp. 835-838.

[8] IAEA (International Atomic Energy Agency), "Summary Report on the Post Accident Review Meeting on the Chernobyl Accident," Safety Series 75, INSAG-1 IAEA, Vienna, 1986.

[9] S. T. Belayev, A. Borovoi, V. Volkov and A. Gagarinski, "Chernobyl Five Years Later," Nuclear Europe Worldscan, No. 3-4, 1991, pp. 22-24.

[10] J. T. Smith, S. V. Fesenko, B. J. Howard, N. I. Sanzharova, R. M. Alexakhin, D. G. Elder and C. Naylor, "Temporal Change in Fallout ${ }^{137} \mathrm{Cs}$ in Terrestrial and Aquatic Systems: A Whole Ecosystem Approach," Environmental Science and Technology, Vol. 33, No. 1, 1999, pp. 49-54. doi:10.1021/es980670t

[11] Z. Papp, Z. Dezsö and S. Daroczy, "Significant Radioactive Contamination of Soil around a Coal-Fired Thermal Power Plant," Journal of Environmental Radioactivity, Vol. 59, No. 2, 2002, pp. 191-205. doi:10.1016/S0265-931X(01)00071-6

[12] P. Tchokossa, J. B. Olomo and O. A. Osibote, "Radioactivity in the Community Water Supplies of Ife-Central and Ife-East Local Government Areas of Osun State, Nigeria," Nuclear Instruments and Methods in Physics Research A, Vol. 422, No. 1-3, 1999, pp. 784-789. doi:10.1016/S0168-9002(98)00997-8

[13] M. K. Fasasi, P. Tchokossa, J. O. Ojo and F. A. Balogun, "Occurrence of Natural Radionuclides and Fallout Cesium-137 in Dry-Season Agricultural Land of South Western Nigeria," Journal of Radioanalytical and Nuclear Chemistry, Vol. 240, No. 3, 1999, pp. 949-952. doi:10.1007/BF02349880

[14] M. K. Fasasi, A. A. Oyawale, C. E. Mokobia, P. Tchokossa, T. R. Ajayi and F. A. Balogun, "Natural Radioactivity of the Tar Sand Deposits of Ondo State, South-Western Nigeria," Nuclear Instruments and Methods in Physics Research A, Vol. 505, No. 1-2, 2003, pp. 449-453. doi:10.1016/S0168-9002(03)01118-5

[15] G. O. Avwiri and P. Tchokossa, "Radiological Impacts of Natural Radioactivity along Aleto River Due to a Petrochemical Industry in Port Harcourt, Rivers State, Nigeria," Journal of Nigerian Environmental Society, Vol. 3, No. 3, 2006, pp. 330-336.

[16] P. Tchokossa, "Radiological Consequences of Oil and Gas Producing Areas in Delta State, Nigeria," Ph.D. Thesis, Obafemi Awolowo University, Ile-Ife, 2006.

[17] G. O. Avwiri, P. Tchokossa and C. E. Mokobia, "Natural Radionuclides in Borehole Water in Port Harcourt, Rivers State, Nigeria," Radiation Protection Dosimetry, Vol. 123, No. 4, 2007, pp. 509-514. doi:10.1093/rpd/ncl526

[18] A. O. Awodugba and P. Tchokossa, "Assessment of Ra- 
dionuclide Concentrations in Water Supply from BoreHoles in Ogbomosoland, Western Nigeria," Indoor and Built Environment, Vol. 17, No. 2, 2008, pp. 183-186. doi:10.1177/1420326X08089551

[19] T. R. Ajayi, N. Torto, P. Tchokossa and A. Akinlua, "Natural Radioactivity and Trace Metals in Crude Oils: Implication for Health," Environmental Geochemistry and Health, Vol. 31, No. 1, 2009, pp. 61-69. doi:10.1007/s10653-008-9155-Z

[20] T. B. Makon, R. M. Nemba and P. Tchokossa, "Investigation of Gamma-Emitting Natural Radioactive Contents in Three Types of Vernonia Consumed in Cameroon," World Journal of Nuclear Science and Technology, Vol. 1, No. 2, 2011, pp. 37-45. doi:10.4236/wjnst.2011.12007

[21] IAEA (International Atomic Energy Agency), "GammaRay Surveys in Uranium Exploration," Technical Report Series 186, Scientific \& Technical Publications, 1979.

[22] E. A. Bryant, et al., "Oklo, an Experiment in Long-Term Geological Storage," Proceedings of the ACS Symposium, Activities in the Environment, New York, 9 April 1976, pp. 89-102.

[23] W. G. Hübschman, "Migration of Radionuclide in Air, Water and Soil. IAEA International Training Course on Determination of Radionuclides in Food and Environmental Samples," School of Nuclear Technology, Nuclear Reactor Center Karlsurhe, Karlsurhe, 1988.

[24] J. P. Lockwood, J. E. Costa, M. L. Tuttle, J. Nni and S. G. Tebor, "The Potential for Catastrophic Dam Failure at Lake Nyos Maar, Cameroon," Volcanology, Vol. 50, No. 5, 1988, pp. 340-349.

[25] S. J. Freeth and R. L. F. Kay, "Possible Risk of Serious Flooding from Lake Nyos," A Memo to Ms Kay Oliver, Charges d'Affaires, Bristish Embassy, Yaounde, 1987.

[26] The Joint Team Cameroon-Nigeria Scientific Team, "Lake Nyos Dam Threats to Cameroon and Nigeria," A Report Submitted to Both Cameroon and Nigeria, 1991.

[27] J. B. Olomo, "The Natural Radioactivity in Some Nigerian Foodstuffs," Nuclear Instruments and Methods in Physics Research A, Vol. 299, No. 1-3, 1990, pp. 666-669. doi:10.1016/0168-9002(90)90866-5

[28] H. L. Beck, J. A. Decampo and C. V. Gogolak, "In Situ $\mathrm{Ge}(\mathrm{Li})$ and $\mathrm{NaI}(\mathrm{Tl})$ Gamma-Ray Spectrometry, Health and Safety Laboratory AEC," Report HASL-28 (US Atomic Energy Commission), New York, 1972.

[29] UNSCEAR (United Nations Scientific Committee on the Effects of Atomic Radiation), "Sources and Effects of Ionizing Radiation," United Nations, New York, 1988.

[30] ICRP (International Commission on Radiological Protection), "ICRP Publication 60: 1990 Recommendations of the International Commission on Radiological Protection," Annals of the ICRP, Vol. 21, No. 1-3, 1991, pp. 1-4. doi:10.1016/0146-6453(91)90065-O

[31] NEA-OCED Radiological Protection NEA/CRPPH, "Dose Constraints in Optimisation of Occupational Radiological Protection,” NEA Group Experts, OCED, Paris, 2011.

[32] A. K. Sam and N. Abbass, "Assessment of Radioactivity and the Associated Hazards in Local and Imported Cement Types Used in Sudan," Radiation Protection Dosimetry, Vol. 93, No. 3, 2001, pp. 275-277. doi:10.1093/oxfordjournals.rpd.a006440

[33] R. Krieger, "Radioactivity of Construction Materials," Betonwerk Fertigteil Technik, Vol. 47, 1981, p. 468

[34] J. Beretka and P. J. Mathew, "Natural Radioactivity of Australian Building Materials, Industrial Wastes and By-Products," Health Physics, Vol. 48, No. 1, 1985, pp. 87-95. doi:10.1097/00004032-198501000-00007

[35] NEA-OCED, "Exposures to Radiation Form Natural Radioactivity in Building Materials," Nuclear Energy Agency, NEA Group Experts, OCED, Paris, 1979.

[36] K. Saito, H. Petoussi and M. Zanki, "Calculation of the Effective Dose and Its Variation from Environmental Gamma Ray Sources," Health Physics, Vol. 74, No. 6, 1998, pp. 698-706. doi:10.1097/00004032-199806000-00007

[37] UNSCEAR (United Nations Scientific Committee on the Effects of Atomic Radiation), "Sources and Effects of Ionizing Radiation," United Nations, New York, 2000

[38] L. S. Quindos, P. L. Fernandez and J. Soto, "Building Materials as Source of Exposure in Houses," In: B. Seifert and H. Esdorn, Eds., Indoor Air 87, Institute for Water, Soil and Air Hygiene, Berlin, 1987, p. 365.

[39] E. Cottens, "Actions against Radon at the International Level,” In: J. Radon, Ed., Proceedings of the Symposium on SRBII, Royal Society of Engineers and Industrials of Belgium, Brussels, 17 January 1990.

[40] M. Iqbal, M. Tufail and M. Mirza, "Measurement of Natural Radioactivity in Marble Found in Pakistan Using NaI(Tl) Gamma-Ray Spectrometer," Journal of Environmental Radioactivity, Vol. 51, No. 2, 2000, pp. 255-265. doi:10.1016/S0265-931X(00)00077-1

[41] D. E. Walling and T. A. Quine, "Application of Caesium-137 in Soil Erosion and Sedimentation Studies (An Introduction)," Report of Hydrology and Earth Surface Processes Research Group, Geography Department, University of Exeter, Exeter, 1993.

[42] IAEA (International Atomic Energy Agency), "Measurements of Radionuclides in Food and the Environment," A Guidebook, Technical Report Series No. 295, LAEA, Vienna, 1989. 